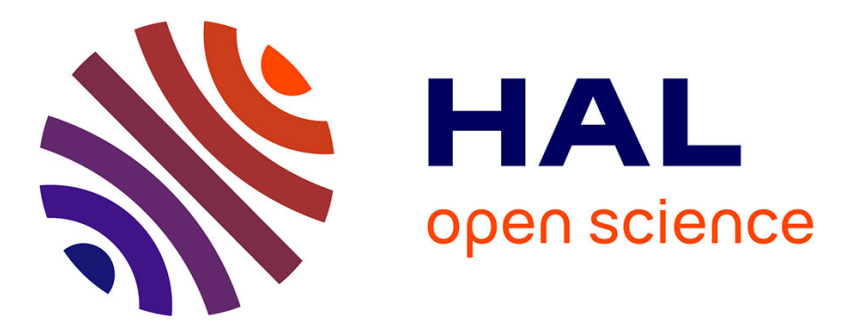

\title{
Competition in dual markets: Implications for banking system stability
}

Tastaftiyan Risfandy, Amine Tarazi, Irwan Trinugroho

\section{To cite this version:}

Tastaftiyan Risfandy, Amine Tarazi, Irwan Trinugroho. Competition in dual markets: Implications for banking system stability. 2018. hal-01757982

\section{HAL Id: hal-01757982 \\ https://hal-unilim.archives-ouvertes.fr/hal-01757982}

Preprint submitted on 4 Apr 2018

HAL is a multi-disciplinary open access archive for the deposit and dissemination of scientific research documents, whether they are published or not. The documents may come from teaching and research institutions in France or abroad, or from public or private research centers.
L'archive ouverte pluridisciplinaire HAL, est destinée au dépôt et à la diffusion de documents scientifiques de niveau recherche, publiés ou non, émanant des établissements d'enseignement et de recherche français ou étrangers, des laboratoires publics ou privés. 


\title{
Competition in dual markets: Implications for banking system stability
}

Tastaftiyan Risfandy ${ }^{1,2, *}$, Amine Tarazi ${ }^{2,3}$, Irwan Trinugroho ${ }^{1}$

${ }^{1}$ Faculty of Economics and Business, Universitas Sebelas Maret, Jl. Ir. Sutami 36A Surakarta 57126 Indonesia

${ }^{2}$ LAPE, Université de Limoges, 5 rue Félix Eboué, 87031 Limoges Cedex, France

${ }^{3}$ Institut Universitaire de France (IUF), 1 rue Descartes, 75231 Paris Cedex 05, France

This version: March 28, 2018

\begin{abstract}
This paper examines the impact of market competition on the stability of Islamic and conventional banks in countries where these banks operate alongside one another. To investigate this issue, we use a sample of 100 Islamic and 390 conventional banks from 19 countries. Our baseline result shows that competition in a dual market erodes banks' stability. The heightened competitive pressure in a dual market encourages banks to engage in excessive risk-taking that can jeopardize their stability. However, the effect of competition is missing for Islamic banks, suggesting their superiority in having religious clients. Although our overall results support the 'competition-fragility' hypothesis, we find that competition can be beneficial for banks, especially at a low to medium competition level. Last, we also find that the adverse impact of competition can be reduced by having high capitalization, especially in the case of a conventional bank. Some policy implications are discussed in the paper.
\end{abstract}

JEL Classifications: D40; G21; G28; Z12

Keywords: Competition, stability, dual banking, Islamic banks, Z-score, Lerner index

*) Corresponding author.

Email: tastaftiyan.risfandy@staff.uns.ac.id or tastaftiyan.risfandy@ unilim.fr (T. Risfandy); amine.tarazi@unilim.fr(A. Tarazi); irwan.trinugroho@gmail.com (I. Trinugroho) 


\section{Introduction}

There is an intense debate in the banking literature on the relationship between competition and stability. A seminal paper by Keeley (1990) initiated the debate by showing that a high level of competition erodes the charter or franchise value (present value of future profitability), which therefore reduces banks' incentives to behave prudently. Under this 'competition-fragility' view, banks cannot earn monopoly rents in a competitive market and hence suffer from weaker profits and lower stability. This hypothesis is supported by some works (Hellmann et al., 2000; Jiménez et al., 2013; Repullo, 2004). Boyd and Nicoló (2005) challenge this argument by promoting the 'competition-stability' hypothesis. Increased competition in the banking market will force banks to give a lower loan rate to the borrower. Accordingly, banks' probability of default is reduced because borrowers have a higher probability of loan repayment. Boyd et al. (2006) and Schaeck et al. (2009), among others, support this view.

In the present paper, we address the relationship between competition and stability in the dual banking market where Islamic and conventional banks operate alongside one another. This is a major issue in banking studies because, according to the data from the World Bank ${ }^{1}$, the dual banking system is now adopted in more than 50 countries. The remarkable growth of Islamic banks in the dual market is likely to have an impact on banks' stability. Are Islamic banks more stable than conventional banks? Does the banking system respond positively to the intensified competition between the two bank types? This paper aims to answer these questions. Additionally, the issue of competition and stability in a dual banking market is interesting because in this banking system, two types of banks compete to attract customers. Despite the fact that Islamic banks are relatively new to the market, conventional banks' behavior in the dual market has changed in reaction to this situation. A recent study by Meslier et al. (2017) shows that conventional banks counter Islamic banks' competitive pressure by setting higher deposit rates when their market power is lower. The behavior of conventional banks, in this case, could jeopardize their financial stability.

Despite the importance of the competition-stability issue in the dual banking system, previous studies in this area are surprisingly muted, many of which investigated competition and stability separately. On the one hand, some prior works highlight competitive conditions in a dual banking system. Using multiple countries data, Turk-Ariss (2010) and Hamza and

\footnotetext{
${ }^{1}$ http://go.worldbank.org/AE0U8AYQ20
} 
Katchouli (2014) highlight that the Islamic banking market is less competitive compared to conventional banking, whereas Weill (2011) does not find significant differences between them. In a similar vein, Cupian and Abduh (2017), using a single country dataset, find that Islamic banks in Indonesia have high market power as an implication of the low degree of competition. On the other hand, a strand of literature has investigated Islamic banks' stability compared to its conventional counterparts. Cihak and Hesse (2010) begin the discussion by providing empirical evidence about Islamic banks' stability relative to their size. They find that small Islamic banks tend to be financially stronger than small conventional banks and large Islamic banks. Abedifar et al. (2013) confirm the finding by showing that small Islamic banks have lower credit risk and are more stable than conventional banks. Beck et al. (2013) highlight that even though Islamic and conventional banks are not different regarding their business model, Islamic banks are better capitalized, have higher asset quality, and are less likely to disintermediate during a crisis. The last finding was also supported recently by Fakhfekh et al. (2016), who observe that Islamic banks are more resilient than conventional banks, although the degree of resilience is heterogeneous and sample dependent.

A recent study by Kabir and Worthington (2017), to the best of our knowledge, is the only study that specifically investigates the impact of market competition on banks' stability in the context of the dual banking system. Their results support the 'competition fragility' hypothesis. They also find that the magnitude of the market power effect on stability is greater for conventional banks than Islamic banks. Although investigating the same issue, this paper will be different in some respects and therefore contribute to the literature in several ways. First, we use different techniques and different variable measurements. Whereas Kabir and Worthington (2017) use panel vector autoregressive (PVAR) and two-stage quantile regression, this paper will use fixed-effect (FE) and two-stages least squares (2SLS). Furthermore, in contrast to Kabir and Worthington (2017), who focus on both accounting (Zscore) and market-based measures of stability (distance-to-default), our approach only focuses on accounting measures because (1) it is directly related to the probability of banks' insolvency $^{2}$, (3) it is popular and widely used in the empirical banking study and is implemented as a time-varying measure in panel studies, and (3) it uses market-based measure stock price data to estimate volatility in the stock price data, but most Islamic banks are not listed in the equity market ${ }^{3}$. In addition, following Leon (2015), rather than using a bank-level

\footnotetext{
${ }^{2}$ For instance, the probability that the value of its assets becomes lower than the value of the debt.

${ }^{3}$ Since we only use accounting measures, we can cover more countries than Kabir and Worthington (2017).
} 
Lerner index as in Kabir and Worthington (2017) to measure competition, we use a weighted average Lerner index at the country level. We believe that this measure will be more appropriate in our case since we investigate the impact of country-level market competition, not bank-level market power. We also use H-Statistics as another proxy of competition at the country level in the robustness section.

Second, in the present paper, we go further by considering the moderating role of capitalization, crisis, and bank size. We investigate whether these conditions may alter the relationship between competition and stability. Our approach is motivated by some prior works highlighting the importance of capitalization, crisis, and bank size on banks' stability. Schliephake (2016) show that bank capitalization moderates the impact of competition on financial stability. Cihak and Hesse (2010) document that smaller Islamic banks have better stability than larger banks, even though Ibrahim and Rizvi (2017) have recently found that larger Islamic banks are stronger. Regarding financial crises, other works show that Islamic banks are more resilient than conventional banks during financial panics (Beck et al., 2013; Farooq and Zaheer, 2015; Hasan and Dridi, 2010; Olson and Zoubi, 2016).

To investigate the above-mentioned issues, we employ a dataset containing 100 Islamic and 390 conventional banks from 19 countries where the dual banking market applies. Our baseline result shows that competition between Islamic and conventional banks in the dual market erodes financial stability. This finding remains consistent after controlling for both bank- and country-specific variables. The finding is also robust either when we use the FE technique or consider the endogeneity problem by using the 2SLS technique. Our result confirms the 'competition-fragility' hypothesis in a dual market proposed by Kabir and Worthington (2017). The heightened competition between Islamic and conventional banks may encourage banks to take excessive risks that could threaten their financial stability. In the next analysis, we find that even though competition promotes financial fragility in the dual market, the impact for Islamic and conventional banks is different. Intensified dual market competition is not significant for Islamic banks where conventional banks are significantly impacted. This result is different from Kabir and Worthington (2017), who find a similar effect for two bank types but is in line with Meslier et al. (2017), who find the missing effect of competition on Islamic banks' deposit rate setting. Islamic banks might benefit from captive clients, making them more stable even in a highly competitive market. Moreover, we also observe in this paper that the different level of competition will yield a different impact on conventional banks' stability. Whereas Islamic banks are not affected either by low or high competitive pressure, 
conventional banks' stability increases when the competition is low, and conversely, it significantly shrinks when competition is high.

Regarding the further analysis, in the present paper, we also find that the competitionstability nexus in the dual market is also altered by bank capitalization and size. Competition promotes financial fragility, but their effect diminishes when banks have high capital ratio (lower solvency risk). This result is consistent with Schliephake (2016). The detrimental effect of competition increases with an increase of the bank's size. It suggests that the competitionfragility nexus is more pronounced in large banks. Banks in the dual market appear to be more stable when operating on a small scale rather than a large scale. Our finding, therefore, supports Cihak and Hesse (2010). Additionally, we also find little evidence that Islamic banks' stability increases with the impact of competition during the crisis period, which is in line with the prior literature highlighting the superiority of Islamic banks during the financial crisis (Farooq and Zaheer, 2015; Hasan and Dridi, 2010; Olson and Zoubi, 2016).

Taking all of the results altogether, this work has various policy implications. Regulators and supervisors should carefully monitor competitive conditions in a dual banking market. The heightened dual market competition could encourage banks, either Islamic or conventional, to take excessive risk that could jeopardize their financial stability. Regulators should also closely monitor banks' capitalization and size since it can moderate the adverse impact of competition. As highlighted by Ibrahim and Rizvi (2017), Islamic banks need to become larger or at least reach a minimum scale for the stabilizing effect of size to be materialized. Islamic banks also need to have sufficient capital buffer because differently from their conventional peers, Islamic banks are subject to displaced commercial risk or the possibility that their depositors move to other banks because of low return payment (Daher et al., 2015).

The structure of our paper is as follows. Section 2 explains the data, variables, and methodology we use. Section 3 presents the result we obtain in this paper, including further analysis and robustness tests. Section 4 concludes the paper.

\section{Data, variables, and methodology}

\subsection{Data}


We extract all of our bank-level dataset from BvD Bankscope. We focus on countries with both Islamic and conventional banks. Following prior work in Islamic banking (Abedifar et al., 2013; Cihak and Hesse, 2010; Meslier et al., 2017), we correct the misclassification issues in Bankscope by cross-checking our Bankscope data, the World Bank dataset in Islamic banks, and each Islamic bank's website. After obtaining the correct Islamic and conventional banks' sample, we create the ratios, winsorize the extreme values at the 1st and 99th percentiles, and retain for banks with a minimum of 4 observations. Our final sample covers 100 Islamic and conventional banks with a total 3458 observations. Regarding country-level data, we obtain the inflation rate and the growth of GDP from the World Bank website. We also use the measure of law enforcement (rule of law) and government efficiency obtained from the world governance indicators (WGI) dataset. Table 1 provides details of the number of banks in each country and some country-level variables.

\section{[Table 1]}

\subsection{Dependent variable: Z-score}

We use the Z-score, which has been extensively applied in the banking literature to measure bank stability. The Z-score measures the standard deviation that the banks' return has to diminish to deplete equity. The Z-score is computed as follows.

$Z_{i t}=\frac{R O A_{i t}+E Q T A_{i t}}{S D R O A} \quad \ldots$

where ROA is return on assets for bank $i$ and year $t$, EQTA is the capital asset ratio for bank $i$ and year $t$, and SDROA is the standard deviation of ROA calculated over the full sample. According to Lepetit and Strobel (2013), the Z-score computation method, as seen in equation (1), are practical because it provides a time-varying z-score without requiring initial observations to be dropped as in the rolling approach. The standard deviation of ROA $\left(\mathrm{SDROA}_{i t}\right)$ that was computed over the full sample as in equation (1), after being tested by Lepetit and Strobel (2013), also provides a lower average RMSE (Root Mean Squared Error) than the rolling moment method. Moreover, our approach in equation (1) has also been used by many works previously (Beck et al., 2013; Cihák and Hesse, 2007; Fiordelisi and Mare, 2014; Fu et al., 2014; Laeven and Levine, 2009) ${ }^{4}$. Because the distribution of the Z-score is highly skewed, we use a natural logarithm of the Z-score (Anginer et al., 2014; Laeven and

\footnotetext{
${ }^{4}$ (Fu et al., 2014) also propose a new method of Z-score computation. We will use it in the robustness section.
} 
Levine, 2009). A higher value of the Z-score means a lower probability of insolvency risk and therefore better bank stability.

\subsection{Independent variable: Lerner index}

The degree of competition in the banking market can be proxied through a traditional industrial organization or newer empirical approaches. The former approach investigates the extent of market competition indirectly through the structural-conduct-performance (SCP) hypothesis, which explains that the level of market power of the bank can be examined through the bank performance. Researchers usually use the concentration ratio, market share, or Herfindahl-Hirschman Index (HHI). The latter approach originated from the inadequacy of traditional measurements because the measures of bank performance that measure SCP theory do not appropriately indicate the degree of bank market power (Claessens and Laeven, 2004). Therefore, the level of bank competition should be measured endogenously (Soedarmono et al., 2011). The popular measurements in a newer empirical approach are the Panzar-Rosse model and the Lerner index. In the present paper, we employ the Lerner index to measure market competition ${ }^{5}$. We do not use traditional measurements of competition (concentration ratios) because prior studies report that bank concentration is an insufficient and ambiguous measure (Berger et al., 2009, 2004) ${ }^{6}$.

The Lerner index corresponds to banks' strength in influencing the price of their banking products. Typically, the Lerner index is a markup of the banks' price of the product over their marginal costs. A higher value Lerner index indicates greater market power. We follow the previous work of Meslier et al. (2017), Turk-Ariss (2010) and Weill (2011) to create the index. The index is computed by the following equation.

Lerner $_{\text {it }}=\frac{\text { Price }_{\text {it }}-\text { MarginalCost }_{\text {it }}}{\text { Price }_{\text {it }}} \quad \ldots$

Price is the ratio of total banks' revenue to total assets. Marginal cost is the first difference of the trans-log cost function as follows.

MarginalCost $=\frac{\text { TotalCosts }}{\text { TotalAssets }}\left(\propto_{1}+\propto_{2} \ln\right.$ TotalAssets $\left.+\sum_{\mathrm{j}=1}^{3} \gamma_{\mathrm{j}} \ln \left(\mathrm{W}_{\mathrm{j}}\right)\right) \ldots$

\footnotetext{
${ }^{5}$ The Panzar-Rosse model will be also used in this paper in the robustness check.

${ }^{6}$ Instead, we will use HHI in the controls to consider the market concentration.
} 


$$
\begin{aligned}
\operatorname{lnTotalCosts}= & \propto_{0}+\propto_{1} \ln \text { TotalAssets }+\frac{1}{2} \propto_{2} \text { lnTotalAssets }^{2}+\sum_{\mathrm{j}=1}^{3} \beta_{\mathrm{j}} \ln \left(\mathrm{W}_{\mathrm{j}}\right) \\
& +\sum_{\mathrm{j}=1}^{3} \sum_{\mathrm{k}=1}^{3} \beta_{\mathrm{jk}} \ln \left(\mathrm{W}_{\mathrm{j}}\right) * \ln \left(\mathrm{W}_{\mathrm{k}}\right)+\sum_{\mathrm{j}=1}^{3} \gamma_{\mathrm{j}} \ln \text { TotalAssets } * \ln \left(\mathrm{W}_{\mathrm{j}}\right)+\varepsilon \quad \ldots
\end{aligned}
$$

where $\mathrm{W}_{\mathrm{j}}$ corresponds to (1) $\mathrm{W}_{1}$ : the price of labor: the ratio of personnel expenses to total assets; (2) $\mathrm{W}_{2}$ : the price of capital: the ratio of other non-interest expenses to fixed assets; and (3) $\mathrm{W}_{3}$ : the price of the fund: the ratio of interest expense to total banks' funding. ${ }^{7}$ The cost function in equation (5) is estimated at the country level using a fixed-effect estimator.

Since we focus on the market-level competition, following Leon (2015) and Meslier et al. (2017), we use the weighted average value of the Lerner index to create a country-level Lerner index (LernerMkt $\mathrm{j}_{\mathrm{j}}$ ). Therefore, the Lerner index can be interpreted directly as a degree of banking market competition instead of bank-level market power. A greater LernerMkt implies lower competition because when competition is high, most of the banks (on average) are not supposed to have strong market power.

\subsection{Controls}

We also include a set of bank-level and country-level controls in our analysis. First, we use net interest margins $\left(\mathrm{NIM}_{\mathrm{it}}\right)$. To calculate NIM, we follow Trinugroho et al. (2014) by employing a ratio of net interest income to total earning assets. According to Fu et al. (2014), it is necessary to employ NIM because we need to control banks' profitability, especially regarding a bank's investing and lending activities. Second, we use LLR it $_{\text {(ratio of loan loss }}$ reserve to total assets) to control banks' credit risk. Soedarmono et al. (2011) note that one of the most important determinants of bank stability is a credit risk. Third, we employ EQTA (capitalization). Abedifar et al. (2013) mention that banks with high capital ratio can have a higher capacity of risk taking, which therefore may influence their financial stability. Schliephake (2016) also find the different effect of competition between high and low capitalized banking sectors. We also control bank size using a log of total assets (LnTA $\left.{ }_{i t}\right)$ as seen in Čihák and Hesse (2010), who observe the different performances of small and large Islamic and conventional banks in dual markets. To control the macroeconomic differences, we use inflation (INFL jt ), GDP Growth $\left(\right.$ GGDP $_{\mathrm{jt}}$ ), and the 2008-2009 financial crisis period

\footnotetext{
${ }^{7}$ Some papers use two factor instead of three factor prices. For instance, see Fu et al. (2014) and Risfandy et al. (2017), among others.
} 
$\left(\right.$ Crisis $\left._{\mathrm{jt}}\right)$. The summary of our variable explanations is provided in Table 2 . We also provide the descriptive statistics and correlation matrix in Tables 3 and 4.

\section{[Table 2]}

[Table 3]

[Table 4]

\subsection{Methodology}

To investigate the impact of market competition on banks' stability, we construct the following equation:

$\mathrm{LnZ}_{\mathrm{it}}=\alpha_{0}+\beta$ LernerMkt $_{\mathrm{jt}}+\varphi \mathrm{X}_{\mathrm{it}-1}+\gamma \mathrm{Z}_{\mathrm{jt}}+\varepsilon_{\mathrm{i}, \mathrm{t}} \quad \ldots \quad$ (5)

where subscripts $i, j$, and $t$ correspond to bank $i$, country $j$, and year $t$. LnZROA $\mathrm{jt}$ is bank stability, LernerMkt $\mathrm{j}_{\mathrm{jt}}$ is the average value of the Lerner index as our measure of market competition, $\mathrm{X}_{\mathrm{it}-1}$ is a vector of bank-level variables (NIM, LLR, EQTA, Size) in a one-year lagged period, and $\mathrm{Z}_{\mathrm{jt}}$ is a vector of country-level variables (INFL, GGDP, Crisis). Equation (5) will be estimated using fixed-effect estimators with the robust standard error clustered at the bank levels.

The prior literature also considers the possible endogeneity problem between banks' market power and stability (Beck et al., 2006; Berger et al., 2004; Schaeck and Cihak, 2010; among others). On the one hand, a bank with a high degree of market power will also have better stability because they are able to determine the price of their product, which is far from their marginal cost. On the other hand, if a bank increases its risk-taking, they will have a higher expected return, which can be converted into higher market power. To address this issue, we will also estimate equation (5) using two-stages least squares (2SLS). Three instruments are used: the lagged value of our competition proxy $\left(\operatorname{LernerMKT}_{\mathrm{jt}-1}\right)$, the rule of law index $\left(\mathrm{Law}_{\mathrm{jt}}\right)$, and government efficiency $\left(\operatorname{GovEff}_{\mathrm{jt}}\right)$. Law $\mathrm{jt}$ and $\operatorname{GovEff}_{\mathrm{jt}}$ are compiled by Kaufmann et al. (2010, 2005) and have also been used by Cihak and Hesse (2010) to manipulate market 
competition $^{8}$. These variables are available online in the World Governance Indicator (WGI) dataset $^{9}$.

\section{Empirical results}

\subsection{Baseline regression}

We estimate equation (5) to test the competition-stability nexus in a banking market that adopts a dual banking system. We provide the result in Table 5.

[Table 5]

In column (1), using the fixed-effect technique, we find a positive sign of the countrylevel Lerner index (LernerMkt), indicating that the higher banks' market power on average (lower competition) is associated with higher banks' stability. This result is confirmed in column (2) when we use the 2SLS estimator. The significant value of LernerMkt is supported by tests of weak identification and over-identification of the instruments we use. We see that the Kleibergen-Paap F Statistics are highly significant (272.6***), confirming that instruments we use in this study are strong enough to explain LernerMkt. The non-significant value of the Hansen J-Statistics (0.147) suggests that our instruments are valid (not correlated with the error term).

Our finding therefore supports the 'competition-fragility' hypothesis, in line with Kabir and Worthington (2017). In dual banking markets, Islamic banks have to compete with both Islamic and conventional banks. Likewise, conventional banks also compete with their conventional and Islamic peers. This condition implies that the degree of competition in the dual banking market has been relatively high. Some studies either indirectly or directly show that heightened competition in the dual market influences Islamic or conventional banks' behavior. For instance, (Charap and Cevik, 2015; Chong and Liu, 2009; Ito, 2013; Saraç and Zeren, 2014) highlight that a higher presence of Islamic banks in banking sectors tends to weaken Islamic banks' own stability. As a response to the competitive pressure of conventional banks, other studies show that Islamic banks adjust their rates of deposit for the sake of

\footnotetext{
${ }^{8}$ The government effectiveness index has also been used by Doumpos et al. (2017) as a determinant of the financial strength index. Similar to Cihak and Hesse (2010), Soedarmono et al. (2011) also use rule of law for instrument market competition.

${ }^{9} \mathrm{http}: / /$ info.worldbank.org/governance/wgi/index.aspx\#home
} 
competition (Abedifar et al., 2016). On the other hand, another study reports that conventional banks' efficiency is also affected by the presence of large Islamic banks in the market (Abedifar et al., 2016). Meslier et al. (2017) document that conventional banks' deposits in the dual banking market are influenced by Islamic banks' market power. Meslier et al. (2017) also argue that conventional banks' response to Islamic banks' competitive pressure could jeopardize their financial stability, especially when they intend to offer higher deposit rates than when their market power is lower.

Turning to the control variables, we observe the significant result of NIM, EQTA, Size, HHI, and INFL. NIM positively affects banks' stability, meaning that the higher profitability of banks will reduce banks' fragility. Banks that can generate more money from their investment and lending activities will be more stable. EQTA is positively related to stability. Banks with more capital ratio, possibly with a higher capital buffer, will be less likely to fail when facing intensified competition in the dual market. Size shows a negative sign, suggesting that banks in the dual market are more stable when they are small. Small banks might be more conservative, whereas larger banks may take more risks. The negative sign is also shown by HHI. In a market with a high concentration (high HHI), banks' stability will be reduced. This suggests that high concentration is not associated with low competition, a similar finding to $\mathrm{Fu}$ et al. (2014). Inflation surprisingly shows a positive impact on banks' stability. It might be associated with the rate offered to clients by the banks. In a high inflation period, banks charge high rates from their customers. The interest income will therefore increase, in addition to the profitability. This condition will result in a lower volatility of profitability (better stability).

\subsection{Islamic and conventional banks subsample}

Since prior studies highlight the possible differences between Islamic and conventional banks' stability (Abedifar et al., 2013; Beck et al., 2013; Cihak and Hesse, 2010, among others), we are interested in seeing whether the impact of competition is also different between two bank types. We then estimate equation (5) within each type of bank separately. The results are presented in Table 6.

\section{[Table 6]}

The results in column (1) and (2) indicate that market competition in the dual banking system is not important for Islamic banks' stability. On the other hand, we see that market 
competition still erodes conventional banks' stability, as displayed in columns (3) and (4). Our results are robust across the estimation techniques (FE and 2SLS) we use.

As documented by Meslier et al. (2017), the way in which Islamic banks compete in the dual banking market is not necessarily similar to that of conventional banks. (DemirgüçKunt et al., 2013; Gheeraert, 2014) show a form of asymmetric competition in which Islamic banks only compete with other Islamic banks but conventional banks compete with both Islamic and conventional banks. This is because the existence of Islamic banks is mainly to fulfill the need of religious customers who hesitate to use conventional banking products (Demirgüç-Kunt et al., 2013; Gheeraert, 2014). Conventional banks will face difficulties in finding religious depositors even after reducing their prices. Conversely, Islamic banks are able to attract both religious and conventional (non-religious) clients, especially when Islamic banks provide better prices. (Ariff, 2014) highlights that Islamic banks at present do not only focus on Muslims. Some Islamic banks even have non-Muslim clientele at approximately 40\% (Ariff, 2014).

\subsection{The different level of market competition}

Motivated by Gheeraert (2014), who finds that the Islamic banking sector plays a role as a complement in dual markets when the Islamic sector reaches a medium penetration level ${ }^{10}$, in this sub-section, we will investigate whether the impact of competition on Islamic and conventional banks' stability will be different in the different level of market competitiveness. We divide our proxy of market competition (LernerMkt) into low (Low LernerMkt, below the 25th percentile), medium (Medium LernerMkt, between the 25th and 75th percentile), and high (High LernerMkt, above 75th percentile). We regress the Islamic banks' stability at each level of the Lerner index we create. The estimation results are presented in Table 7.

\section{[Table 7]}

The results in Table 7 suggest that the impact of market competition on banks' stability depends on the intensity of the competition. However, this provides mixed results. We observe that especially in conventional banks' cases, the 'competition-fragility' hypothesis only occurs when the degree of competition is high because a positive sign of our competition proxies appear only in columns (11) and (12). On the contrary, competition favors conventional banks'

\footnotetext{
${ }^{10}$ Accordingly, Imam and Kpodar (2013) also document that Islamic banks appear to complement rather than substitute for conventional banks.
} 
stability at the low and medium competition levels, as displayed in columns (7) to (10). In the Islamic banks subsample, we also find some evidence in column (3) that banks' stability increases as the market becomes more competitive. This result support 'competition-stability' view. Dual market competition could be an advantage for both Islamic and conventional banks because, according to (Boyd and Nicoló, 2005), it will force banks to offer a lower loan rate to the borrower. This condition will be good for banks' stability because a lower loan rate will make entrepreneurs less eager to take excessive risks and thus increase the probability of entrepreneurs' loan repayment (Boyd and Nicoló, 2005). However, note that the benefits of competition occur only at the low to medium competition level. At the high level, competition will deteriorate the banks' stability.

3.4. Further analysis: Capitalization, crisis, and size of banks.

The preceding studies on financial stability underline the importance of bank capitalization, the financial crisis period, and bank size. (Schliephake, 2016) theoretically show that, by looking at the regulatory perspective, imposing capital requirements without considering the competitive environment can have adverse effects on stability. It is also documented that the competitive market does not play a role in well-capitalized banking sectors (Schliephake, 2016). In other words, bank capitalization moderates the impact of competition on bank stability. Therefore, we complement the theoretical work of Schliephake (2016) by testing whether there is a possible interaction effect between bank capitalization and competition regarding the competition-stability nexus. Our econometric setup is as follows.

$$
\begin{gathered}
\text { LnZ }_{\mathrm{it}}=\alpha_{0}+\beta_{1} \text { LernerMkt }_{\mathrm{jt}}+\beta_{2} \text { EQTA }_{\mathrm{it}}+\beta_{3} \text { LernerMkt }_{\mathrm{jt}} * \mathrm{EQTA}_{\mathrm{it}}+\varphi \mathrm{X}_{\mathrm{it}-1}+\gamma \mathrm{Z}_{\mathrm{jt}} \\
+\varepsilon_{\mathrm{i}, \mathrm{t}} \quad \ldots \quad(6)
\end{gathered}
$$

In studies on Islamic banks, another work by Cihak and Hesse (2010) shows the significance of banks' size on Islamic banks' stability. They document that Islamic banks are more stable when operating at a small scale and less stable when operating at a large scale. However, recently, Ibrahim and Rizvi (2017) find an opposite result. They suggest that larger Islamic banks are more stable, at least when they surpass a certain threshold size. To refine the two contradictory findings, we construct the following equation containing the interaction effect LernerMkt ${ }_{\mathrm{jt}} *$ Size $_{\mathrm{it}}$.

$$
\begin{gathered}
\text { LnZ }_{\mathrm{it}}=\alpha_{0}+\beta_{1} \text { LernerMkt }_{\mathrm{jt}}+\beta_{2} \text { Size }_{\mathrm{it}}+\beta_{3} \text { LernerMkt }_{\mathrm{jt}} * \text { Size }_{\mathrm{it}}+\varphi \mathrm{X}_{\mathrm{it}-1}+\gamma \mathrm{Z}_{\mathrm{jt}} \\
+\varepsilon_{\mathrm{i}, \mathrm{t}} \quad \ldots \quad(7)
\end{gathered}
$$


The next investigation in this section is about the banking crisis. Some studies claim that Islamic banks perform better during the financial crisis. Hasan and Dridi (2010) find that Islamic banks on average showed stronger resilience during the financial crisis. Accordingly, Beck et al. (2013) document that Islamic banks are less likely to disintermediate during the crisis. Alqahtani et al. (2016), using GCC data, highlight that Islamic banks are more cost efficient in comparison to conventional banks. Olson and Zoubi (2016) observe that Islamic banks initially weathered the onslaught of the global financial crisis better than their conventional peers. Farooq and Zaheer (2015) find that by using data from Pakistan, Islamic banks are more resilient during financial crises. We therefore construct the following equation to investigate specific effects of the financial crisis.

$$
\begin{gathered}
\text { LnZ }_{\mathrm{it}}=\alpha_{0}+\beta_{1} \text { LernerMkt }_{\mathrm{jt}}+\beta_{2} \text { Crisis }_{\mathrm{jt}}+\beta_{3} \text { LernerMkt }_{\mathrm{jt}} * \text { Crisis }_{\mathrm{jt}}+\varphi \mathrm{X}_{\mathrm{it}-1}+\gamma \mathrm{Z}_{\mathrm{jt}} \\
+\varepsilon_{\mathrm{i}, \mathrm{t}} \quad \ldots \quad \text { (8) }
\end{gathered}
$$

Table 8 shows the impact of the above-mentioned three variables in the competitionstability nexus. The result is as follows. First, from columns (1) and (7), the negative interaction coefficients suggest that bank capitalization (EQTA) reduces the impact of market competition on banks' stability. In the marginal effect rows, we can also see that market competition has positively affected banks stability both in low and medium bank capitalization, but the coefficients become lower (Low $0.542 * * *>$ Medium $0.447 * * *$ ). The coefficient even becomes insignificant (0.0895) when EQTA is high, suggesting that the impact of market competition diminishes for banks with a high capital ratio. Our results are in line with Schliephake (2016). In other words, the detrimental impact of market competition can be reduced when banks possess a high capital ratio. This evidence is seen in conventional banks and in all samples.

Second, regarding the impact of a financial crisis, in column (5), we find a little evidence that the crisis period moderates the impact of dual market competition on Islamic banks' stability $\left(\beta_{3}=-0.457^{*}\right)$, even though the impact of market competition is statistically insignificant, both in the crisis period $\left(\beta_{1}+\beta_{3}=-0.240\right)$ and in the non-crisis period $\left(\beta_{1}=0.217\right)$. In the conventional bank subsample, although competition positively affects stability both in the crisis $\left(\beta_{1}+\beta_{3}=0.422 * * *\right)$ and non-crisis periods $\left(\beta_{1}=0.499 * * *\right)$, there is no statistical support that a crisis alters the competition-stability nexus $\left(\beta_{3}=-0.0577\right)$. Our result generally supports the prior literature highlighting the superiority of Islamic banks during the crisis than conventional banks. 
Third, we find that a higher bank size will strengthen the detrimental impact of competition on banks' stability. This is depicted in columns (3), (6) and (9). In the conventional bank sample, the marginal effect of coefficients increase in accordance with bank size (Low = $\left.0.390 * * *>\mathrm{Med}=0.485^{* * *}>\mathrm{High}=0.719 * * *\right)$, suggesting that the detrimental impact will be higher when the bank size is larger. In Islamic banks, we only find a significant effect of competition when Islamic banks become large $\left(\beta_{1}+\beta_{3}\right.$ (High) $\left.=0.678^{* *}\right)$. This partially confirms the previous findings of Cihak and Hesse (2010). They find that Islamic banks are better when operating at a small scale.

\subsection{Robustness checks}

To improve the validity of our results, some robustness tests are conducted in this paper. First, we change our stability proxy by a Z-score measurement proposed by Lepetit and Strobel (2013). They claim that their method is more robust and free from potentially 'spurious' volatility related to the construction of time-varying Z-scores. This measure is calculated using mean and standard deviation estimates of ROA that are calculated over the full sample and combines these with the current values of CAR. The result is presented in Table 9. It still supports the 'competition-fragility' hypothesis. Second, as explained earlier, for a robustness check, we also use another non-structural measurement of competition: H-Statistic. Similar to the Lerner index, the greater value of the H-Statistic is associated with the more competitive market. We follow the method proposed by Turk-Ariss (2010) to compute H-Statistics. Our result, as depicted in table 10, is also similar. Third, instead of using three input cost functions to calculate the Lerner index, we use two input cost functions following (Beck et al., 2013; Fu et al., 2014). In the emerging market studies, the two-cost function is more popular due to the data unavailability because it only needs the data of total interest expense $\left(\mathrm{W}_{1}\right)$ and total noninterest expense $\left(\mathrm{W}_{2}\right)$. However, our results remain unchanged using both the FE and 2SLS methods, as depicted in Table 11.

[Table 9]

[Table 10]

[Table 11]

\section{Conclusion}


This paper investigates the role of competition on the stability of Islamic and conventional banks in countries where the two banks operate alongside one another. This paper is motivated by the heightened competitive condition in the dual market that may encourage either Islamic or conventional banks' willingness to take excessive risks. This condition might jeopardize their stability, as suggested in some studies. To investigate the issue, we use a sample of 490 Islamic and conventional banks from 19 countries. We employ a market-level Lerner index to proxy market competitiveness and the Z-score to measure banks' stability. Our main result shows that market competition erodes banks' stability, giving support to the 'competition-fragility' nexus. This condition is robust after controlling for bank and countryspecific variables. Our result also remains consistent across the estimation techniques we use. In the second analysis, however, we find that the 'competition-fragility' hypothesis does not hold for Islamic banks. The effect of competition on Islamic banks is missing. On the other hand, Islamic banks are not affected by competitive pressure in the dual market, possibly because of the religious clients they have. In addition, when we repartition our competition variable into low, medium, and high, we find that the 'competition-fragility' hypothesis only occurs in the high competition market. Competition can favor financial stability, especially when they are at low or medium levels.

In a further analysis, we find that the detrimental impact of market competition can be reduced when banks possess a high capital ratio, especially for conventional banks. We also find a negative impact of bank size on the 'competition-fragility' nexus. The adverse impact of competition will be stronger for large banks than small banks. It appears that banks in the dual market are better operating at a small scale. Last, we find little evidence that a crisis period moderates the impact of dual market competition on Islamic banks' stability. Islamic banks appear to be stronger than conventional banks during a crisis period, as also suggested by some prior studies.

\section{References}

Abedifar, P., Hasan, I., Tarazi, A., 2016. Finance-Growth Nexus and Dual-Banking Systems: Relative Importance of Islamic Banks. J. Econ. Behav. Organ. 1-18. https://doi.org/10.2139/ssrn.2614180

Abedifar, P., Molyneux, P., Tarazi, A., 2013. Risk in Islamic Banking. Rev. Financ. 17, 2035- 
2096. https://doi.org/10.1093/rof/rfs041

Alqahtani, F., Mayes, D.G., Brown, K., 2016. Economic turmoil and Islamic banking: Evidence from the Gulf Cooperation Council. Pacific Basin Financ. J. 39, 44-56. https://doi.org/10.1016/j.pacfin.2016.05.017

Anginer, D., Demirgüç-Kunt, A., Zhu, M., 2014. How does deposit insurance affect bank risk? Evidence from the recent crisis. J. Bank. Financ. 48, 312-321. https://doi.org/10.1016/j.jbankfin.2013.09.013

Ariff, M., 2014. Whither Islamic Banking? World Econ. 37, 733-746. https://doi.org/10.1111/twec.12171

Beck, T., Demirgüç-Kunt, A., Levine, R., 2006. Bank concentration, competition, and crises: $\begin{array}{lllll}\text { First } & \text { results. } & \text { J. } & \text { Bank. }\end{array}$ https://doi.org/10.1016/j.jbankfin.2005.05.010

Beck, T., Demirgüç-Kunt, A., Merrouche, O., 2013. Islamic vs. conventional banking: Business model, efficiency and stability. J. Bank. Financ. 37, 433-447. https://doi.org/10.1016/j.jbankfin.2012.09.016

Berger, A.N., Demirgüç-kunt, A., Levine, R., Haubrich, J.G., 2004. Bank Concentration and Competition: An Evolution in the Making. J. Money, Credit Bank. 36, 433-451.

Berger, A.N., Klapper, L.F., Turk-Ariss, R., 2009. Bank Competition and Financial Stability. J. Financ. Serv. Res. 35, 99-118. https://doi.org/10.1007/s10693-008-0050-7

Boyd, J.H., De Nicoló, G., Jalal, A.M., 2006. Bank Risk-Taking and Competition Revisited: New Theory and New Evidence. IMF Work. Pap. 6, 1. https://doi.org/10.5089/9781451865578.001

Boyd, J.H., Nicoló, G. De, 2005. The Theory of Bank Risk Taking and Competition Revisited. J. Finance 60, 1329-1343.

Charap, J., Cevik, S., 2015. The Behavior of Conventional and Islamic Bank Deposit Returns in Malaysia and Turkey. Int. J. Econ. Financ. Issues 5, 111-124. https://doi.org/10.5089/9781455293704.001

Chong, B.S., Liu, M.-H., 2009. Islamic banking: Interest-free or interest-based? Pacific-Basin 
Financ. J. 17, 125-144. https://doi.org/10.1016/j.pacfin.2007.12.003

Cihak, M., Hesse, H., 2010. Islamic Banks and Financial Stability: An Empirical Analysis. J. Financ. Serv. Res. 38, 95-113. https://doi.org/10.1007/s10693-010-0089-0

Cihák, M., Hesse, H., 2007. Cooperative Banks and Financial Stability. IMF Work. Pap. 7, 36. https://doi.org/10.5089/9781451865660.001

Claessens, S., Laeven, L., 2004. What Drives Bank Competition? Some International Evidence. J. Money, Credit Bank. 36, 563-583. https://doi.org/10.2307/3838954

Cupian, Abduh, M., 2017. Competitive Condition and Market Power of Islamic Bank in Indonesia. Int. J. Islam. Middle East. Financ. Manag. 8, 134-149. https://doi.org/10.1108/17538391111144515

Daher, H., Masih, M., Ibrahim, M., 2015. The unique risk exposures of Islamic banks' capital buffers: A dynamic panel data analysis. J. Int. Financ. Mark. Institutions Money 36, 3652. https://doi.org/10.1016/j.intfin.2015.02.012

Demirgüç-Kunt, A., Klapper, L.F., Randall, D., 2013. Islamic finance and financial inclusion: Measuring use and demand for formal financial services among muslim adults (No. 6642), World Bank Policy Research Working Paper.

Doumpos, M., Hasan, I., Pasiouras, F., 2017. Bank overall financial strength: Islamic versus conventional banks. Econ. Model. https://doi.org/10.1016/j.econmod.2017.03.026

Fakhfekh, M., Hachicha, N., Jawadi, F., Selmi, N., Idi Cheffou, A., 2016. Measuring volatility persistence for conventional and Islamic banks: An FI-EGARCH approach. Emerg. Mark. Rev. 27, 84-99. https://doi.org/10.1016/j.ememar.2016.03.004

Farooq, M., Zaheer, S., 2015. Are Islamic Banks More Resilient During Financial Panics? Pacific Econ. Rev. 20, 101-124. https://doi.org/10.1111/1468-0106.12096

Fiordelisi, F., Mare, D.S., 2014. Competition and financial stability in European cooperative banks. J. Int. Money Financ. 45, 1-16. https://doi.org/10.1016/j.jimonfin.2014.02.008

Fu, X., Lin, Y., Molyneux, P., 2014. Bank competition and financial stability in Asia Pacific. J. Bank. Financ. 38, 64-77. https://doi.org/10.1016/j.jbankfin.2013.09.012

Gheeraert, L., 2014. Does Islamic finance spur banking sector development? J. Econ. Behav. 
Organ. 103, S4-S20. https://doi.org/10.1016/j.jebo.2014.02.013

Hamza, H., Katchouli, S., 2014. Competitive conditions and market power of Islamic and conventional commercial banks. J. Islam. Account. Bus. Res. 5, 29-46.

Hasan, M., Dridi, J., 2010. The Effects of the Global Crisis on Islamic and Conventional Banks: A Comparative Study (No. WP/10/201), IMF Working Paper. https://doi.org/10.1142/S1793993311000270

Hellmann, T.F., Murdock, K.C., Stiglitz, J.E., 2000. Liberalization, moral hazard in banking, and prudential regulation: are capital requirements enough? Am. Econ. Rev. 90, 147-165. https://doi.org/10.1257/aer.90.1.147

Ibrahim, M.H., Rizvi, S.A.R., 2017. Do we need bigger Islamic banks? An assessment of bank stability. J. Multinatl. Financ. Manag. 1, 1-38. https://doi.org/10.1016/j.mul

Imam, P., Kpodar, K., 2013. Islamic Banking: How Has It Expanded? Emerg. Mark. Financ. Trade 49, 112-137. https://doi.org/10.2753/REE1540-496X490607

Ito, T., 2013. Islamic rates of return and conventional interest rates in the Malaysian deposit market. Int. J. Islam. Middle East. Financ. Manag. Vol. 6, 290-303. https://doi.org/10.1108/IMEFM-11-2012-0113

Jiménez, G., Lopez, J.A., Saurina, J., 2013. How does competition affect bank risk-taking? J. Financ. Stab. 9, 185-195. https://doi.org/10.1016/j.jfs.2013.02.004

Kabir, M.N., Worthington, A.C., 2017. The "competition-stability/fragility" nexus: A comparative analysis of Islamic and conventional banks. Int. Rev. Financ. Anal. 50, 111128. https://doi.org/10.1016/j.irfa.2017.02.006

Kaufmann, D., Kraay, A., Mastruzzi, M., 2010. The Worldwide Governance Indicators: Methodology and Analytical Issues (No. 5430), World Bank Policy Research Working Paper.

Kaufmann, D., Kraay, A., Mastruzzi, M., 2005. Governance Matters IV: Governance Indicators for 1996-2004 (No. WPS3630), World Bank Policy Research Working Paper.

Keeley, M.C., 1990. Deposit Insurance, Risk, and Market Power in Banking. Am. Econ. Rev. $80,1183-1200$. 
Laeven, L., Levine, R., 2009. Bank governance, regulation and risk taking. J. financ. econ. 93, 259-275. https://doi.org/10.1016/j.jfineco.2008.09.003

Leon, F., 2015. Does bank competition alleviate credit constraints in developing countries? J. Bank. Financ. 57, 130-142. https://doi.org/10.1016/j.jbankfin.2015.04.005

Lepetit, L., Nys, E., Rous, P., Tarazi, A., 2008. Bank income structure and risk: An empirical analysis of European banks. J. Bank. Financ. 32, 1452-1467. https://doi.org/10.1016/j.jbankfin.2007.12.002

Lepetit, L., Strobel, F., 2013. Bank insolvency risk and time-varying Z-score measures. J. Int. Financ. Mark. Institutions Money 25, 73-78. https://doi.org/10.1016/j.frl.2015.01.001

Meslier, C., Risfandy, T., Tarazi, A., 2017. Dual market competition and deposit rate setting in Islamic and conventional banks. Econ. Model. 63, 318-333. https://doi.org/http://dx.doi.org/10.1016/j.econmod.2017.02.013

Olson, D., Zoubi, T., 2016. Convergence in bank performance for commercial and Islamic banks during and after the Global Financial Crisis. Q. Rev. Econ. Financ. https://doi.org/http://dx.doi.org/10.1016/j.qref.2016.06.013

Repullo, R., 2004. Capital requirements, market power, and risk-taking in banking. J. Financ. Intermediation 13, 156-182. https://doi.org/10.1016/j.jfi.2003.08.005

Risfandy, T., Trinarningsiih, W., Harmadi, H., Trinugroho, I., 2017. Islamic Banks' market power, state-owned banks, and Ramadan: Evidence from Indonesia. Singapore Econ. Rev. 1-18. https://doi.org/10.1142/S0217590817500229

Saraç, M., Zeren, F., 2014. The dependency of Islamic bank rates on conventional bank interest rates: further evidence from Turkey. Appl. Econ. 47, 669-679. https://doi.org/10.1080/00036846.2014.978076

Schaeck, K., Cihak, M., 2010. Banking Competition and Capital Ratios. Eur. Financ. Manag. 18, 836-866. https://doi.org/10.1111/j.1468-036X.2010.00551.x

Schaeck, K., Cihak, M., Wolfe, S., 2009. Are Competitive Banking Systems More Stable? J. Money, Credit Bank. 41, 711-734.

Schliephake, E., 2016. Capital Regulation and Competition as a Moderator for Banking 
Stability. J. Money, Credit Bank. 48, 1787-1814.

Soedarmono, W., Machrouh, F., Tarazi, A., 2011. Bank market power, economic growth and financial stability: Evidence from Asian banks. J. Asian Econ. 22, 460-470. https://doi.org/10.1016/j.asieco.2011.08.003

Trinugroho, I., Agusman, A., Tarazi, A., 2014. Why have bank interest margins been so high in Indonesia since the 1997/1998 financial crisis? Res. Int. Bus. Financ. 32, 139-158. https://doi.org/10.1016/j.ribaf.2014.04.001

Turk-Ariss, R., 2010. Competitive conditions in Islamic and conventional banking: A global perspective. Rev. Financ. Econ. 19, 101-108. https://doi.org/10.1016/j.rfe.2010.03.002

Weill, L., 2011. Do Islamic Banks Have Greater Market Power? Comp. Econ. Stud. 53, 291306. https://doi.org/10.1057/ces.2011.1 
Table 1. The number of banks in sample countries and some country-level variables.

\begin{tabular}{lrrrrrrr}
\hline Country & $\begin{array}{r}\text { Islamic } \\
\text { banks }\end{array}$ & $\begin{array}{r}\text { Conv. } \\
\text { banks }\end{array}$ & LernerMkt & HSTAT & HHI & Law & GovEff \\
\hline Bahrain & 12 & 9 & 0.192 & n.a. & 0.158 & 0.487 & 0.504 \\
Bangladesh & 5 & 27 & 0.208 & 0.634 & 0.085 & -0.827 & -0.760 \\
Egypt & 2 & 21 & 0.135 & n.a. & 0.146 & -0.325 & -0.581 \\
Indonesia & 3 & 64 & 0.281 & 0.425 & 0.097 & -0.672 & -0.277 \\
Iraq & 1 & 3 & 0.292 & n.a. & 0.157 & -1.555 & -1.163 \\
Jordan & 3 & 9 & 0.282 & 0.390 & 0.373 & 0.364 & 0.130 \\
Kenya & 1 & 29 & 0.320 & 0.386 & 0.109 & -0.887 & -0.544 \\
Kuwait & 9 & 5 & 0.444 & n.a. & 0.186 & 0.561 & 0.082 \\
Malaysia & 16 & 25 & 0.291 & 0.386 & 0.091 & 0.502 & 1.085 \\
Pakistan & 7 & 22 & 0.256 & n.a. & 0.106 & -0.853 & -0.640 \\
Qatar & 3 & 6 & 0.486 & n.a. & 0.270 & 0.798 & 0.716 \\
Saudi Arabia & 6 & 7 & 0.467 & 0.194 & 0.115 & 0.175 & -0.134 \\
South Africa & 1 & 15 & 0.204 & 0.564 & 0.288 & 0.100 & 0.507 \\
Sudan & 14 & 2 & 0.214 & n.a. & 0.301 & -1.340 & -1.315 \\
Tunisia & 1 & 8 & 0.318 & n.a. & 0.116 & 0.051 & 0.292 \\
Turkey & 4 & 25 & 0.146 & 0.434 & 0.122 & 0.076 & 0.290 \\
United Arab Emirates & 8 & 17 & 0.448 & 0.501 & 0.102 & 0.530 & 0.948 \\
United Kingdom & 2 & 93 & 0.219 & 0.442 & 0.128 & 1.682 & 1.672 \\
Yemen & 2 & 3 & 0.274 & n.a. & 0.284 & -1.144 & -1.051 \\
\hline Total & 100 & 390 & & & & & \\
Mean & & & 0.274 & 0.438 & 0.139 & 0.181 & 0.343 \\
\hline
\end{tabular}


Table 2. Variables description.

\begin{tabular}{|c|c|c|c|}
\hline Variable & Definition & Primary references & Source \\
\hline $\mathrm{LnZ}_{\text {it }}$ & $\begin{array}{l}\text { Log of Z-score to measure bank } \\
\text { stability. }\end{array}$ & (Lepetit and Strobel, 2013) & $\begin{array}{l}\text { Bankscope, Authors } \\
\text { calculation }\end{array}$ \\
\hline LnAltZ $Z_{\text {it }}$ & $\begin{array}{l}\text { An alternative measurement of the } \\
\text { Z-score }\end{array}$ & (Leon, 2015; Meslier et al., 2017) & $\begin{array}{l}\text { Bankscope, Authors } \\
\text { calculation }\end{array}$ \\
\hline LernerMkt $_{\mathrm{jt}}$ & $\begin{array}{l}\text { The country weighted-average } \\
\text { value of banks' Lerner index to } \\
\text { measure market competition. The } \\
\text { Lerner index is calculated using a } \\
\text { trans-log cost function with three } \\
\text { input prices. }\end{array}$ & (Fu et al., 2014) & $\begin{array}{l}\text { Bankscope, Authors } \\
\text { calculation }\end{array}$ \\
\hline AltLernerMkt $_{j t}$ & $\begin{array}{l}\text { An alternative measurement of the } \\
\text { Lerner index. It is a weighted } \\
\text { average of banks' Lerner index that } \\
\text { is calculated using the trans-log } \\
\text { cost function with two input prices. }\end{array}$ & (Turk-Ariss, 2010) & $\begin{array}{l}\text { Bankscope, Authors } \\
\text { calculation }\end{array}$ \\
\hline $\mathrm{HSTAT}_{\mathrm{jt}}$ & $\begin{array}{l}\text { H-statistic derived from the Panzar } \\
\text { and Rosse model. }\end{array}$ & $\begin{array}{l}\text { (Fu et al., 2014; Trinugroho et al., } \\
\text { 2014) }\end{array}$ & $\begin{array}{l}\text { Bankscope, Authors } \\
\text { calculation }\end{array}$ \\
\hline $\mathrm{NIM}_{\mathrm{it}-1}$ & $\begin{array}{l}\text { Lag value of net interest margins to } \\
\text { proxy banks' profitability. It is a } \\
\text { ratio of net interest income to total } \\
\text { earning assets. }\end{array}$ & (Soedarmono et al., 2011) & $\begin{array}{l}\text { Bankscope, Authors } \\
\text { calculation }\end{array}$ \\
\hline $\operatorname{LLR}_{\mathrm{it}-1}$ & $\begin{array}{l}\text { Lag value of the ratio of loan loss } \\
\text { reserve to total assets to measure } \\
\text { credit risk. }\end{array}$ & $\begin{array}{l}\text { (Abedifar et al., 2013; Schliephake, } \\
\text { 2016) }\end{array}$ & $\begin{array}{l}\text { Bankscope, Authors } \\
\text { calculation }\end{array}$ \\
\hline EQTA $_{\text {it-1 }}$ & $\begin{array}{l}\text { Lag value of the capital asset ratio } \\
\text { to measure banks' solvency. }\end{array}$ & (Cihak and Hesse, 2010) & $\begin{array}{l}\text { Bankscope, Authors } \\
\text { calculation }\end{array}$ \\
\hline Size $_{i t-1}$ & $\begin{array}{l}\text { Lag value of the natural logarithm } \\
\text { of total assets to measure banks' } \\
\text { size. }\end{array}$ & (Berger et al., 2009) & $\begin{array}{l}\text { Bankscope, Authors } \\
\text { calculation }\end{array}$ \\
\hline $\mathrm{HHI}_{\mathrm{jt}}$ & $\begin{array}{l}\text { Herfindahl Hirschman index to } \\
\text { proxy market concentration. }\end{array}$ & (Soedarmono et al., 2011) & $\begin{array}{l}\text { Bankscope, Authors } \\
\text { calculation }\end{array}$ \\
\hline $\mathrm{INFL}_{\mathrm{jt}}$ & Inflation & (Soedarmono et al., 2011) & World bank website \\
\hline $\mathrm{GGDP}_{\mathrm{jt}}$ & Growth of GDP & (Cihak and Hesse, 2010) & World bank website \\
\hline Crisis $_{j t}$ & Crisis & (Kaufmann et al., 2010, 2005) & \\
\hline $\mathrm{Law}_{\mathrm{jt}}$ & $\begin{array}{l}\text { The rule of law index. Ranges from } \\
-2.5 \text { (weak) to } 2.5 \text { (strong). }\end{array}$ & (Kaufmann et al., 2010, 2005) & $\begin{array}{l}\text { Worldwide } \\
\text { governance indicator } \\
\text { (WGI) dataset }\end{array}$ \\
\hline GovEff $_{\mathrm{jt}}$ & $\begin{array}{l}\text { Government efficiency index. } \\
\text { Ranges from }-2.5 \text { (weak) to } 2.5 \\
\text { (strong). }\end{array}$ & (Kaufmann et al., 2010, 2005) & $\begin{array}{l}\text { Worldwide } \\
\text { governance indicator } \\
\text { (WGI) dataset }\end{array}$ \\
\hline
\end{tabular}


Table 3. Descriptive statistics

\begin{tabular}{lcrrrr}
\hline Variable & Obs. & Mean & Std. Dev. & Min & Max \\
\hline LnZ $_{\text {it }}$ & 3892 & 1.6171 & 0.5584 & 0.2812 & 3.1734 \\
LnAltZ & 3892 & 1.6405 & 0.4996 & 0.7014 & 3.0557 \\
LernerMkt $_{\mathrm{jt}}$ & 3892 & 0.2833 & 0.1094 & -0.0215 & 0.5931 \\
AltLernerMkt $_{\mathrm{jt}}$ & 3890 & 0.2656 & 0.1601 & -0.3203 & 0.4709 \\
HSTAT $_{\mathrm{jt}}$ & 3022 & 0.4359 & 0.1854 & 0.0911 & 0.8424 \\
NIM $_{\mathrm{it}-1}$ & 3892 & 0.0380 & 0.0253 & -0.0144 & 0.2118 \\
LLR $_{\mathrm{it}-1}$ & 3892 & 0.0529 & 0.0684 & 0.0008 & 0.4737 \\
EQTA $_{\mathrm{it}-1}$ & 3892 & 0.1314 & 0.0871 & 0.0368 & 0.5028 \\
Size $_{\mathrm{it}-1}$ & 3892 & 14.7372 & 2.0117 & 9.6159 & 19.7465 \\
HHI $_{\mathrm{jt}}$ & 3892 & 0.1359 & 0.0823 & 0.0425 & 0.7715 \\
INFL $_{\mathrm{jt}}$ & 3892 & 0.0672 & 0.0650 & -0.2422 & 0.3742 \\
GGDP $_{\mathrm{jt}}$ & 3892 & 0.0191 & 0.0357 & -0.1734 & 0.1431 \\
Crisi $_{\mathrm{jt}}$ & 3892 & 0.1680 & 0.3739 & 0.0000 & 1.0000 \\
Law $_{\mathrm{jt}}$ & 3892 & 0.1957 & 0.9217 & -1.7715 & 1.8869 \\
GovEff $_{\mathrm{jt}}$ & 3892 & 0.3555 & 0.8802 & -1.5569 & 1.9000 \\
\hline
\end{tabular}

Note: Please see Table 2 for the variable descriptions.

Table 4. Correlation matrix

\begin{tabular}{|c|c|c|c|c|c|c|c|c|c|c|c|}
\hline & & (1) & (2) & (3) & (4) & (5) & (6) & (7) & (8) & (9) & (10) \\
\hline (1) & $\operatorname{LnZ}_{\text {it }}$ & 1 & & & & & & & & & \\
\hline (2) & LernerMkt $_{\mathrm{jt}}$ & 0.269 & 1 & & & & & & & & \\
\hline (3) & NIM $_{\mathrm{it}-1}$ & 0.329 & 0.012 & 1 & & & & & & & \\
\hline (4) & $\operatorname{LLR}_{\mathrm{it}-1}$ & 0.161 & -0.034 & 0.082 & 1 & & & & & & \\
\hline (5) & EQTA $_{\text {it-1 }}$ & 0.832 & 0.167 & 0.243 & 0.224 & 1 & & & & & \\
\hline (6) & Size $_{\mathrm{it}-1}$ & -0.382 & 0.119 & -0.280 & -0.232 & -0.401 & 1 & & & & \\
\hline (7) & $\mathrm{HHI}_{\mathrm{jt}}$ & 0.033 & -0.056 & -0.016 & 0.131 & 0.029 & -0.100 & 1 & & & \\
\hline (8) & INFL $_{\mathrm{jt}}$ & 0.118 & 0.018 & 0.191 & 0.074 & 0.052 & -0.167 & 0.045 & 1 & & \\
\hline (9) & GGDP $_{j t}$ & -0.037 & -0.095 & 0.130 & -0.017 & -0.059 & -0.120 & -0.022 & 0.158 & 1 & \\
\hline (10) & Crisis $_{\mathrm{jt}}$ & -0.020 & -0.041 & 0.027 & -0.059 & -0.013 & 0.026 & -0.047 & -0.020 & -0.370 & 1 \\
\hline
\end{tabular}

Note: Please see Table 2 for the variable descriptions. 
Table 5. Banks' stability in the dual banking market

\begin{tabular}{|c|c|c|}
\hline & $\begin{array}{l}\mathrm{FE} \\
(1)\end{array}$ & $\begin{array}{l}2 \text { SLS } \\
(2)\end{array}$ \\
\hline LernerMkt $_{\mathrm{jt}}$ & $\begin{array}{l}0.449 * * * \\
(4.44)\end{array}$ & $\begin{array}{l}0.491 * * * \\
(3.07)\end{array}$ \\
\hline $\mathrm{NIM}_{\text {it-1 }}$ & $\begin{array}{l}1.731 * * * \\
(3.49)\end{array}$ & $\begin{array}{l}1.720 * * * \\
(3.39)\end{array}$ \\
\hline $\operatorname{LLR}_{\mathrm{it}-1}$ & $\begin{array}{l}0.158 \\
(1.05)\end{array}$ & $\begin{array}{l}0.161 \\
(1.34)\end{array}$ \\
\hline EQTA $_{\text {it- } 1}$ & $\begin{array}{l}3.284 * * * \\
(18.79)\end{array}$ & $\begin{array}{l}3.283 * * * \\
(18.93)\end{array}$ \\
\hline Size $_{i t-1}$ & $\begin{array}{l}-0.0652 * * * \\
(-3.62)\end{array}$ & $\begin{array}{l}-0.0660 \text { *** } \\
(-4.16)\end{array}$ \\
\hline $\mathrm{HHI}_{\mathrm{jt}}$ & $\begin{array}{l}-0.624 * * * \\
(-3.97)\end{array}$ & $\begin{array}{l}-0.618 * * * \\
(-4.94)\end{array}$ \\
\hline $\mathrm{INFL}_{\mathrm{jt}}$ & $\begin{array}{l}0.287 * * * \\
(3.06)\end{array}$ & $\begin{array}{l}0.287 * * * \\
(3.14)\end{array}$ \\
\hline $\mathrm{GGDP}_{\mathrm{jt}}$ & $\begin{array}{l}0.280 \\
(1.56)\end{array}$ & $\begin{array}{l}0.265^{*} \\
(1.81)\end{array}$ \\
\hline Crisis $_{j t}$ & $\begin{array}{l}0.0432 \\
(1.33) \\
\end{array}$ & $\begin{array}{l}0.0402 \\
(1.31) \\
\end{array}$ \\
\hline $\mathrm{N}$ obs & 3892 & 3892 \\
\hline $\mathrm{N}$ group & 490 & 490 \\
\hline R-sq. & 0.339 & \\
\hline KP F-Stat. & & $272.6 * * *$ \\
\hline Hansen J-Stat. & & 0.147 \\
\hline \multicolumn{3}{|c|}{$\begin{array}{l}\text { Notes: This table provides the estimation results of equation (5) using fixed effect (FE) } \\
\text { and two-stages least squares (2SLS) techniques. The validity of the instruments is } \\
\text { tested using KP (Kleibergen Paap) F-Statistics and Hansen J-Statistics. Please refer to } \\
\text { Table } 2 \text { for a description of the variables. } * * *, * * \text {, and } * \text { denote significance at the } 1 \% \text {, } \\
5 \% \text {, and } 10 \% \text { levels, respectively. }\end{array}$} \\
\hline
\end{tabular}


Table 6. The impact of market competition on Islamic and conventional banks' stability.

\begin{tabular}{|c|c|c|c|c|}
\hline & \multicolumn{2}{|c|}{ Islamic banks } & \multicolumn{2}{|c|}{ Conventional banks } \\
\hline & $\begin{array}{l}\mathrm{FE} \\
(1)\end{array}$ & $\begin{array}{l}2 \text { SLS } \\
(2)\end{array}$ & $\begin{array}{l}\mathrm{FE} \\
(3)\end{array}$ & $\begin{array}{l}2 \text { SLS } \\
(4)\end{array}$ \\
\hline LernerMkt $_{\mathrm{jt}}$ & $\begin{array}{l}0.189 \\
(0.95)\end{array}$ & $\begin{array}{l}0.325 \\
(0.70)\end{array}$ & $\begin{array}{l}0.492 * * * \\
(4.49)\end{array}$ & $\begin{array}{l}0.448^{* *} \\
(2.49)\end{array}$ \\
\hline $\mathrm{NIM}_{\mathrm{it}-1}$ & $\begin{array}{l}-0.462 \\
(-0.56)\end{array}$ & $\begin{array}{l}-0.481 \\
(-0.33)\end{array}$ & $\begin{array}{l}2.259 * * * \\
(3.60)\end{array}$ & $\begin{array}{l}2.275^{* * * *} \\
(4.30)\end{array}$ \\
\hline $\mathrm{LLR}_{\mathrm{it}-1}$ & $\begin{array}{l}0.249 \\
(0.84)\end{array}$ & $\begin{array}{l}0.250 \\
(1.13)\end{array}$ & $\begin{array}{l}0.198 \\
(1.20)\end{array}$ & $\begin{array}{l}0.195 \\
(1.44)\end{array}$ \\
\hline EQTA $_{\text {it- } 1}$ & $\begin{array}{l}3.471 * * * \\
(9.52)\end{array}$ & $\begin{array}{l}3.476 * * * \\
(10.10)\end{array}$ & $\begin{array}{l}3.128 * * * \\
(15.85)\end{array}$ & $\begin{array}{l}3.131 * * * \\
(15.77)\end{array}$ \\
\hline Size $_{\text {it- } 1}$ & $\begin{array}{l}-0.0338 \\
(-0.69)\end{array}$ & $\begin{array}{l}-0.0305 \\
(-0.82)\end{array}$ & $\begin{array}{l}-0.0703 * * * \\
(-3.53)\end{array}$ & $\begin{array}{l}-0.0693 * * * \\
(-3.92)\end{array}$ \\
\hline $\mathrm{HHI}_{\mathrm{jt}}$ & $\begin{array}{l}-0.488 * * \\
(-2.58)\end{array}$ & $\begin{array}{l}-0.520 * * * \\
(-2.81)\end{array}$ & $\begin{array}{l}-0.795 * * * \\
(-3.15)\end{array}$ & $\begin{array}{l}-0.815 * * * \\
(-3.77)\end{array}$ \\
\hline $\mathrm{INFL}_{\mathrm{jt}}$ & $\begin{array}{l}0.612 * * * \\
(3.01)\end{array}$ & $\begin{array}{l}0.611 * * * \\
(3.12)\end{array}$ & $\begin{array}{l}0.146^{*} \\
(1.71)\end{array}$ & $\begin{array}{l}0.146^{*} \\
(1.74)\end{array}$ \\
\hline $\mathrm{GGDP}_{\mathrm{jt}}$ & $\begin{array}{l}0.664 * \\
(1.89)\end{array}$ & $\begin{array}{l}0.626^{*} \\
(1.95)\end{array}$ & $\begin{array}{l}0.115 \\
(0.66)\end{array}$ & $\begin{array}{l}0.133 \\
(0.88)\end{array}$ \\
\hline Crisis $_{j t}$ & $\begin{array}{l}0.111 \\
(1.24) \\
\end{array}$ & $\begin{array}{l}0.0921 \\
(0.98) \\
\end{array}$ & $\begin{array}{l}0.0319 \\
(0.90) \\
\end{array}$ & $\begin{array}{l}0.0344 \\
(1.05) \\
\end{array}$ \\
\hline N obs. & 640 & 640 & 3252 & 3252 \\
\hline $\mathrm{N}$ banks & 100 & 100 & 390 & 390 \\
\hline R-sq & 0.410 & & 0.342 & \\
\hline KP F-Stat. & & $25.01 * * *$ & & $258.5^{* * *}$ \\
\hline Hansen J-Stat. & & 0.347 & & 0.201 \\
\hline
\end{tabular}


Table 7. The impact of different market competition levels on banks' stability

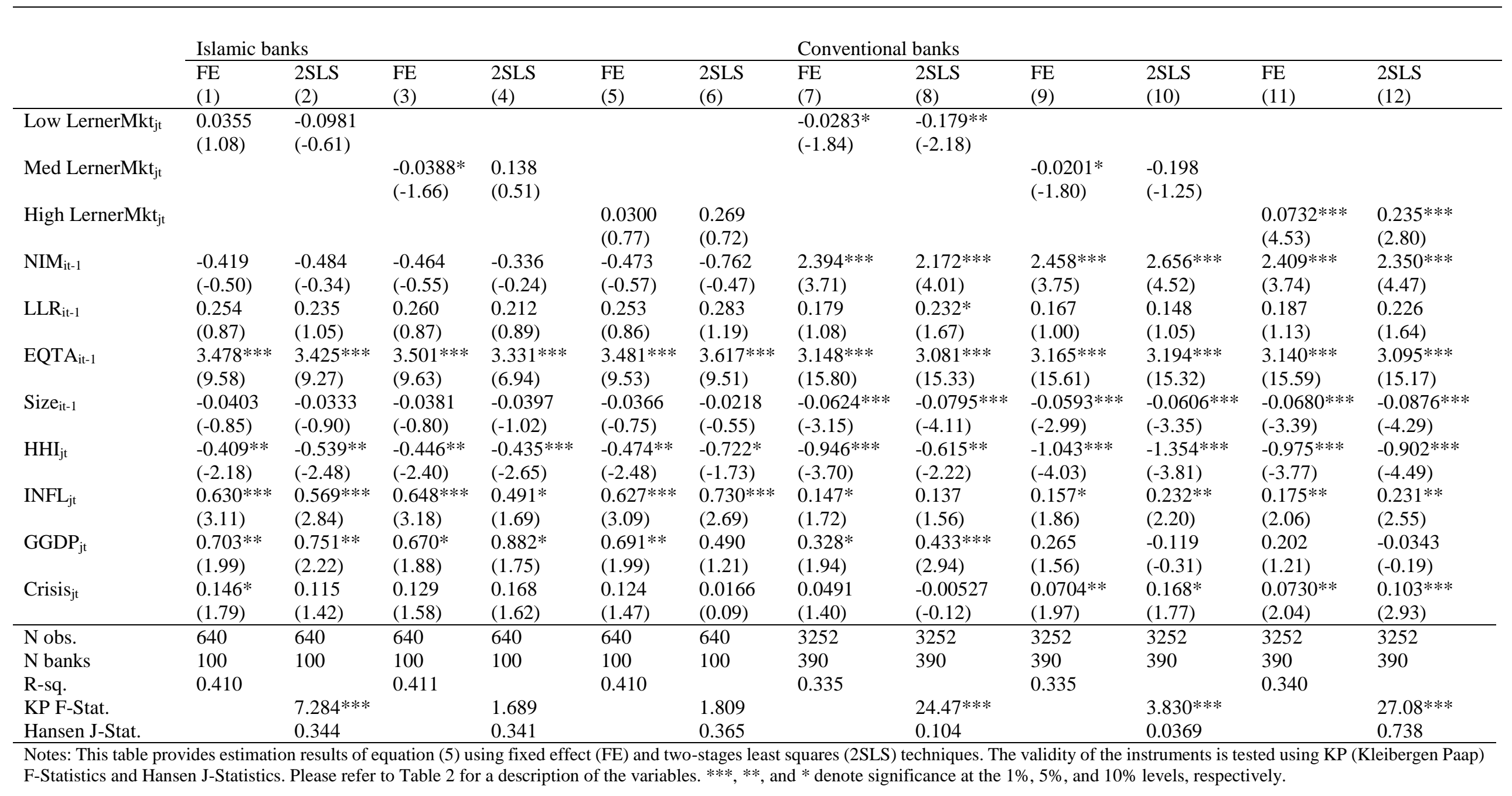


Table 8. Lerner index, capitalization, crisis, and size

\begin{tabular}{|c|c|c|c|c|c|c|c|c|c|}
\hline & All sample & & & Islamic ba & & & Conventiona & banks & \\
\hline & (1) & (2) & (3) & (4) & (5) & (6) & (7) & (8) & (9) \\
\hline LernerMkt $_{\mathrm{jt}}\left(\beta_{1}\right)$ & $\begin{array}{l}0.697 * * * * \\
(4.64)\end{array}$ & $\begin{array}{l}0.466 * * * \\
(4.53)\end{array}$ & $\begin{array}{l}-0.462 \\
(-0.86)\end{array}$ & $\begin{array}{l}0.514^{*} \\
(1.75)\end{array}$ & $\begin{array}{l}0.217 \\
(1.07)\end{array}$ & $\begin{array}{l}-1.326 \\
(-1.17)\end{array}$ & $\begin{array}{l}0.764 * * * \\
(4.71)\end{array}$ & $\begin{array}{l}0.499 * * * \\
(4.47)\end{array}$ & $\begin{array}{l}-0.514 \\
(-0.89)\end{array}$ \\
\hline $\mathrm{EQTA}_{\mathrm{it-1}}\left(\beta_{2}\right)$ & $\begin{array}{l}3.835 * * * \\
(11.77)\end{array}$ & $\begin{array}{l}3.284 * * * \\
(18.82)\end{array}$ & $\begin{array}{l}3.272 * * * \\
(18.71)\end{array}$ & $\begin{array}{l}4.295 * * * \\
(7.21)\end{array}$ & $\begin{array}{l}3.482 * * * \\
(9.58)\end{array}$ & $\begin{array}{l}3.491 * * * \\
(9.73)\end{array}$ & $\begin{array}{l}3.712 * * * \\
(10.23)\end{array}$ & $\begin{array}{l}3.126 * * * \\
(15.86)\end{array}$ & $\begin{array}{l}3.107 * * * \\
(15.72)\end{array}$ \\
\hline $\operatorname{Crisis}_{\mathrm{jt}}\left(\beta_{2}\right)$ & $\begin{array}{l}0.0440 \\
(1.36)\end{array}$ & $\begin{array}{l}0.0896 * * \\
(2.06)\end{array}$ & $\begin{array}{l}0.0433 \\
(1.34)\end{array}$ & $\begin{array}{l}0.137 \\
(1.50)\end{array}$ & $\begin{array}{l}0.250 * * \\
(2.10)\end{array}$ & $\begin{array}{l}0.0843 \\
(0.95)\end{array}$ & $\begin{array}{l}0.0315 \\
(0.89)\end{array}$ & $\begin{array}{l}0.0482 \\
(1.05)\end{array}$ & $\begin{array}{l}0.0332 \\
(0.94)\end{array}$ \\
\hline $\operatorname{Size}_{i t-1}\left(\beta_{2}\right)$ & $\begin{array}{l}-0.0639^{* * * *} \\
(-3.56)\end{array}$ & $\begin{array}{l}-0.0658 * * * \\
(-3.65)\end{array}$ & $\begin{array}{l}-0.0843^{* * * *} \\
(-3.93)\end{array}$ & $\begin{array}{l}-0.0408 \\
(-0.88)\end{array}$ & $\begin{array}{l}-0.0329 \\
(-0.68)\end{array}$ & $\begin{array}{l}-0.0658 \\
(-1.17)\end{array}$ & $\begin{array}{l}-0.0689 * * * \\
(-3.49)\end{array}$ & $\begin{array}{l}-0.0706^{* * * *} \\
(-3.54)\end{array}$ & $\begin{array}{l}-0.0911^{* * * *} \\
(-3.88)\end{array}$ \\
\hline LernerMkt*EQTA $\left(\beta_{3}\right)$ & $-2.038^{* *}$ & & & -2.449 & & & $-2.284 * *$ & & \\
\hline & $(-2.25)$ & & & $(-1.60)$ & & & $(-2.25)$ & & \\
\hline LernerMkt*Crisis $\left(\beta_{3}\right)$ & & -0.163 & & & $-0.457^{*}$ & & & -0.0577 & \\
\hline & & $(-1.57)$ & & & $(-1.82)$ & & & $(-0.56)$ & \\
\hline LernerMkt*Size $\left(\beta_{3}\right)$ & & & $0.0629 *$ & & & 0.111 & & & $0.0681 *$ \\
\hline & & & $(1.79)$ & & & $(1.43)$ & & & $(1.81)$ \\
\hline Marginal effect & & & & & & & & & \\
\hline$\beta_{1}+\beta_{3}$ (Low) & $0.542 * * *$ & & $0.373 * * *$ & 0.328 & & 0.143 & $0.590^{* * *}$ & & $0.390^{* * *}$ \\
\hline & $(4.98)$ & & $(3.20)$ & $(1.48)$ & & $(0.67)$ & $(5.04)$ & & (3.06) \\
\hline$\beta_{1}+\beta_{3}(\mathrm{Med})$ & $0.477 * * *$ & & $0.461 * * *$ & 0.250 & & 0.297 & $0.518^{* * * *}$ & & $0.485^{* * *}$ \\
\hline & $(4.73)$ & & $(4.58)$ & $(1.23)$ & & $(1.54)$ & $(4.74)$ & & $(4.39)$ \\
\hline$\beta_{1}+\beta_{3}$ (High) & $\begin{array}{l}0.0895 \\
(0.48)\end{array}$ & & $\begin{array}{l}0.677 * * * \\
(4.57)\end{array}$ & $\begin{array}{l}-0.216 \\
(-0.70)\end{array}$ & & $\begin{array}{l}0.678^{* *} \\
(1.97)\end{array}$ & $\begin{array}{l}0.0832 \\
(0.39)\end{array}$ & & $\begin{array}{l}0.719 * * * \\
(4.49)\end{array}$ \\
\hline $\begin{array}{l}\text { Wald test } \\
\beta_{1}+\beta_{3}\end{array}$ & & $0.303 * *$ & & & -0.240 & & & $0.442 * * *$ & \\
\hline
\end{tabular}


(2.34)

N obs. $3892 \quad 3892$

3892

$\mathrm{N}$ banks.

$490 \quad 490$

490
0.340

$(-0.78)$

R-sq.

0.34

640

0.340

$\begin{array}{ll}100 & 100 \\ 0.414 & 0.415\end{array}$

640

100

0.413

$(3.27)$

Notes: This table provides estimation results for equations (6), (7), and (8) using the fixed effect (FE) technique. Please refer to Table 2 for a description of the variables. ***,

$* *$, and $*$ denote significance at the $1 \%, 5 \%$, and $10 \%$ levels, respectively. 
Table 9. Robustness: Alternative proxy of Z-Score (LnAltZ $\left.Z_{i t}\right)$ following Lepetit and Strobel (2013)

\begin{tabular}{|c|c|c|c|c|c|c|}
\hline & \multicolumn{2}{|l|}{ All sample } & \multicolumn{2}{|c|}{ Islamic banks } & \multicolumn{2}{|c|}{ Conventional banks } \\
\hline & $\begin{array}{l}\text { FE } \\
(1)\end{array}$ & $\begin{array}{l}2 \text { SLS } \\
(2) \\
\end{array}$ & $\begin{array}{l}\mathrm{FE} \\
\text { (3) }\end{array}$ & $\begin{array}{l}2 \text { SLS } \\
\text { (4) }\end{array}$ & $\begin{array}{l}\mathrm{FE} \\
(5)\end{array}$ & $\begin{array}{l}2 \mathrm{SLS} \\
(6)\end{array}$ \\
\hline LernerMkt $_{j t}$ & $\begin{array}{l}0.301 * * * \\
(3.84)\end{array}$ & $\begin{array}{l}0.437 * * * \\
(3.35)\end{array}$ & $\begin{array}{l}0.110 \\
(0.64)\end{array}$ & $\begin{array}{l}0.161 \\
(0.43)\end{array}$ & $\begin{array}{l}0.361 * * * \\
(4.33)\end{array}$ & $\begin{array}{l}0.503^{* * * *} \\
(3.28)\end{array}$ \\
\hline $\mathrm{NIM}_{\mathrm{it}-1}$ & $\begin{array}{l}0.961 * * \\
(2.53)\end{array}$ & $\begin{array}{l}0.927 * * \\
(2.43)\end{array}$ & $\begin{array}{l}-0.450 \\
(-0.77)\end{array}$ & $\begin{array}{l}-0.457 \\
(-0.69)\end{array}$ & $\begin{array}{l}1.293 * * * \\
(2.62)\end{array}$ & $\begin{array}{l}1.242 * * * \\
(2.81)\end{array}$ \\
\hline $\operatorname{LLR}_{\mathrm{it}-1}$ & $\begin{array}{l}0.274 * * \\
(2.29)\end{array}$ & $\begin{array}{l}0.282 * * * \\
(2.86)\end{array}$ & $\begin{array}{l}0.212 \\
(1.01)\end{array}$ & $\begin{array}{l}0.212 \\
(1.38)\end{array}$ & $\begin{array}{l}0.331 * * \\
(2.48)\end{array}$ & $\begin{array}{l}0.340 * * * \\
(3.01)\end{array}$ \\
\hline EQTA $_{\text {itt } 1}$ & $\begin{array}{l}3.223 * * * \\
(19.96)\end{array}$ & $\begin{array}{l}3.218 * * * \\
(21.31)\end{array}$ & $\begin{array}{l}3.360 * * * \\
(11.20)\end{array}$ & $\begin{array}{l}3.362^{* * * *} \\
(13.47)\end{array}$ & $\begin{array}{l}3.044 * * * \\
(16.40)\end{array}$ & $\begin{array}{l}3.034 * * * \\
(17.07)\end{array}$ \\
\hline Size $_{\text {it- } 1}$ & $\begin{array}{l}-0.0490 * * * \\
(-3.05)\end{array}$ & $\begin{array}{l}-0.0515^{* * * *} \\
(-3.84)\end{array}$ & $\begin{array}{l}0.0270 \\
(1.23)\end{array}$ & $\begin{array}{l}0.0282 \\
(1.30)\end{array}$ & $\begin{array}{l}-0.0649 * * * \\
(-3.84)\end{array}$ & $\begin{array}{l}-0.0681^{* * *} \\
(-4.46)\end{array}$ \\
\hline $\mathrm{HHI}_{\mathrm{jt}}$ & $\begin{array}{l}-0.369 * * * \\
(-3.22)\end{array}$ & $\begin{array}{l}-0.351 * * * \\
(-3.68)\end{array}$ & $\begin{array}{l}-0.265^{*} \\
(-1.94)\end{array}$ & $\begin{array}{l}-0.277^{*} \\
(-1.86)\end{array}$ & $\begin{array}{l}-0.549 * * * \\
(-2.99)\end{array}$ & $\begin{array}{l}-0.487 * * * \\
(-2.82)\end{array}$ \\
\hline $\mathrm{INFL}_{\mathrm{jt}}$ & $\begin{array}{l}0.197 * * * \\
(3.48)\end{array}$ & $\begin{array}{l}0.196 * * * \\
(3.46)\end{array}$ & $\begin{array}{l}0.337 * * * \\
(2.89)\end{array}$ & $\begin{array}{l}0.336^{* * *} \\
(3.09)\end{array}$ & $\begin{array}{l}0.165 * * * \\
(2.75)\end{array}$ & $\begin{array}{l}0.164 * * * \\
(2.59)\end{array}$ \\
\hline $\mathrm{GGDP}_{\mathrm{jt}}$ & $\begin{array}{l}0.0320 \\
(0.28)\end{array}$ & $\begin{array}{l}-0.0135 \\
(-0.13)\end{array}$ & $\begin{array}{l}0.243 \\
(1.40)\end{array}$ & $\begin{array}{l}0.229 \\
(1.02)\end{array}$ & $\begin{array}{l}-0.0473 \\
(-0.35)\end{array}$ & $\begin{array}{l}-0.103 \\
(-0.84)\end{array}$ \\
\hline Crisis $_{\mathrm{jt}}$ & $\begin{array}{l}0.0661 * * * \\
(2.60)\end{array}$ & $\begin{array}{l}0.0566 \text { ** } \\
(2.30)\end{array}$ & $\begin{array}{l}0.0632 \\
(0.97)\end{array}$ & $\begin{array}{l}0.0561 \\
(0.74)\end{array}$ & $\begin{array}{l}0.0630 * * \\
(2.32)\end{array}$ & $\begin{array}{l}0.0551 \text { ** } \\
(2.12)\end{array}$ \\
\hline $\mathrm{N}$ obs. & 3892 & 3892 & 640 & 640 & 3252 & 3252 \\
\hline N banks. & 490 & 490 & 100 & 100 & 390 & 390 \\
\hline R-sq. & 0.421 & & 0.519 & & 0.419 & \\
\hline KP F-Stat. & & $180.2 * * *$ & & $14.76 * * *$ & & $175.6 * * *$ \\
\hline Hansen J-Stat. & 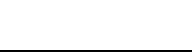 & 0.487 & 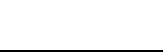 & 0.166 & 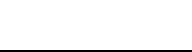 & 0.218 \\
\hline
\end{tabular}


Table 10. Robustness: Using H-Statistics from the Panzar-Rosse model

\begin{tabular}{|c|c|c|c|c|c|c|}
\hline & \multicolumn{2}{|l|}{ All samples } & \multicolumn{2}{|c|}{ Islamic banks } & \multicolumn{2}{|c|}{ Conventional banks } \\
\hline & $\begin{array}{l}\text { FE } \\
(1) \\
\end{array}$ & $\begin{array}{l}2 \text { SLS } \\
(2)\end{array}$ & $\begin{array}{l}\mathrm{FE} \\
(3) \\
\end{array}$ & $\begin{array}{l}2 \text { SLS } \\
(4)\end{array}$ & $\begin{array}{l}\mathrm{FE} \\
(5) \\
\end{array}$ & $\begin{array}{l}2 \text { SLS } \\
(6)\end{array}$ \\
\hline $\operatorname{HSTAT}_{\mathrm{jt}}$ & $\begin{array}{l}0.0748 * * * \\
(2.76)\end{array}$ & $\begin{array}{l}0.682 * * * \\
(2.62)\end{array}$ & $\begin{array}{l}0.00153 \\
(0.02)\end{array}$ & $\begin{array}{l}1.271 \\
(0.93)\end{array}$ & $\begin{array}{l}0.0759 * * * \\
(2.70)\end{array}$ & $\begin{array}{l}0.443 * * \\
(2.07)\end{array}$ \\
\hline $\mathrm{NIM}_{\mathrm{it}-1}$ & $\begin{array}{l}2.100 * * * \\
(3.27)\end{array}$ & $\begin{array}{l}2.153 * * * \\
(3.72)\end{array}$ & $\begin{array}{l}-0.611 \\
(-0.35)\end{array}$ & $\begin{array}{l}1.609 \\
(0.49)\end{array}$ & $\begin{array}{l}2.237 * * * \\
(3.20)\end{array}$ & $\begin{array}{l}2.236^{* * * *} \\
(3.83)\end{array}$ \\
\hline $\operatorname{LLR}_{\mathrm{it}-1}$ & $\begin{array}{l}0.372 * * \\
(2.07)\end{array}$ & $\begin{array}{l}0.307 * \\
(1.93)\end{array}$ & $\begin{array}{l}0.404 \\
(1.08)\end{array}$ & $\begin{array}{l}0.0878 \\
(0.16)\end{array}$ & $\begin{array}{l}0.377 * * \\
(2.02)\end{array}$ & $\begin{array}{l}0.330 * * \\
(1.98)\end{array}$ \\
\hline EQTA $_{\text {it-1 }}$ & $\begin{array}{l}3.164 * * * \\
(15.75)\end{array}$ & $\begin{array}{l}3.238 * * * \\
(16.24)\end{array}$ & $\begin{array}{l}3.103 * * * \\
(6.46)\end{array}$ & $\begin{array}{l}3.843^{* * * *} \\
(4.32)\end{array}$ & $\begin{array}{l}3.126 * * * \\
(14.37)\end{array}$ & $\begin{array}{l}3.151 * * * \\
(15.16)\end{array}$ \\
\hline Size $_{i t-1}$ & $\begin{array}{l}-0.0466^{* *} \\
(-2.17)\end{array}$ & $\begin{array}{l}-0.0244 \\
(-1.10)\end{array}$ & $\begin{array}{l}0.0131 \\
(0.24)\end{array}$ & $\begin{array}{l}0.0872 \\
(0.77)\end{array}$ & $\begin{array}{l}-0.0478 * * \\
(-2.13)\end{array}$ & $\begin{array}{l}-0.0380 * \\
(-1.85)\end{array}$ \\
\hline $\mathrm{HHI}_{\mathrm{jt}}$ & $\begin{array}{l}-1.126^{* * *} \\
(-3.98)\end{array}$ & $\begin{array}{l}-0.734 * * * \\
(-2.66)\end{array}$ & $\begin{array}{l}-0.279 \\
(-0.47)\end{array}$ & $\begin{array}{l}1.695 \\
(0.76)\end{array}$ & $\begin{array}{l}-1.249 * * * \\
(-4.15)\end{array}$ & $\begin{array}{l}-1.042 * * * \\
(-4.34)\end{array}$ \\
\hline $\mathrm{INFL}_{\mathrm{jt}}$ & $\begin{array}{l}0.0932 \\
(1.00)\end{array}$ & $\begin{array}{l}0.0395 \\
(0.37)\end{array}$ & $\begin{array}{l}0.121 \\
(0.56)\end{array}$ & $\begin{array}{l}0.745 \\
(0.95)\end{array}$ & $\begin{array}{l}0.0985 \\
(0.95)\end{array}$ & $\begin{array}{l}0.0512 \\
(0.45)\end{array}$ \\
\hline $\mathrm{GGDP}_{\mathrm{jt}}$ & $\begin{array}{l}0.384 * * \\
(2.07)\end{array}$ & $\begin{array}{l}0.494 * * * \\
(2.71)\end{array}$ & $\begin{array}{l}0.699 * * \\
(2.31)\end{array}$ & $\begin{array}{l}0.665 \\
(1.21)\end{array}$ & $\begin{array}{l}0.372 * \\
(1.71)\end{array}$ & $\begin{array}{l}0.460 * * \\
(2.41)\end{array}$ \\
\hline Crisis $_{\mathrm{jt}}$ & $\begin{array}{l}-0.0223 \\
(-0.62) \\
\end{array}$ & $\begin{array}{l}-0.0211 \\
(-0.60) \\
\end{array}$ & $\begin{array}{l}-0.00555 \\
(-0.05)\end{array}$ & $\begin{array}{l}-0.341 \\
(-0.84) \\
\end{array}$ & $\begin{array}{l}-0.0226 \\
(-0.76) \\
\end{array}$ & $\begin{array}{l}-0.00772 \\
(-0.28) \\
\end{array}$ \\
\hline $\mathrm{N}$ obs. & 3022 & 3022 & 334 & 334 & 2688 & 2688 \\
\hline $\mathrm{N}$ banks & 360 & 360 & 49 & 49 & 311 & 311 \\
\hline R-sq. & 0.350 & & 0.413 & & 0.354 & \\
\hline KP F-Stat. & & $8.253 * * *$ & & 0.576 & & $9.419 * * *$ \\
\hline Hansen J-Stat. & & 0.166 & & 0.455 & & 0.0862 \\
\hline
\end{tabular}


Table 11. Robustness: Alternative proxy of LernerMkt using a two-factor input price following Fu et al. (2014)

\begin{tabular}{|c|c|c|c|c|c|c|}
\hline & \multicolumn{2}{|l|}{ All sample } & \multicolumn{2}{|c|}{ Islamic banks } & \multicolumn{2}{|c|}{ Conventional banks } \\
\hline & $\begin{array}{l}\mathrm{FE} \\
(1) \\
\end{array}$ & $\begin{array}{l}2 \text { SLS } \\
(2)\end{array}$ & $\begin{array}{l}\mathrm{FE} \\
(3) \\
\end{array}$ & $\begin{array}{l}2 \mathrm{SLS} \\
(4)\end{array}$ & $\begin{array}{l}\mathrm{FE} \\
(5)\end{array}$ & $\begin{array}{l}2 \text { SLS } \\
(6)\end{array}$ \\
\hline AltLernerMkt ${ }_{j t}$ & $\begin{array}{l}0.238 * * * \\
(2.82)\end{array}$ & $\begin{array}{l}0.322 * * * \\
(3.28)\end{array}$ & $\begin{array}{l}0.0641 \\
(0.42)\end{array}$ & $\begin{array}{l}0.253 \\
(1.12)\end{array}$ & $\begin{array}{l}0.332 * * * \\
(3.60)\end{array}$ & $\begin{array}{l}0.316^{* * * *} \\
(2.91)\end{array}$ \\
\hline $\mathrm{NIM}_{\mathrm{it}-1}$ & $\begin{array}{l}1.805^{* * * *} \\
(3.60)\end{array}$ & $\begin{array}{l}1.792 * * * \\
(3.55)\end{array}$ & $\begin{array}{l}-0.430 \\
(-0.52)\end{array}$ & $\begin{array}{l}-0.407 \\
(-0.29)\end{array}$ & $\begin{array}{l}2.341 * * * \\
(3.67)\end{array}$ & $\begin{array}{l}2.346 * * * \\
(4.44)\end{array}$ \\
\hline $\operatorname{LLR}_{\text {it- } 1}$ & $\begin{array}{l}0.117 \\
(0.77)\end{array}$ & $\begin{array}{l}0.113 \\
(0.94)\end{array}$ & $\begin{array}{l}0.233 \\
(0.79)\end{array}$ & $\begin{array}{l}0.235 \\
(1.06)\end{array}$ & $\begin{array}{l}0.150 \\
(0.90)\end{array}$ & $\begin{array}{l}0.151 \\
(1.11)\end{array}$ \\
\hline EQTA $_{\text {it-1 }}$ & $\begin{array}{l}3.304 * * * \\
(18.70)\end{array}$ & $\begin{array}{l}3.305 * * * \\
(18.94)\end{array}$ & $\begin{array}{l}3.506 * * * \\
(9.23)\end{array}$ & $\begin{array}{l}3.542 * * * \\
(9.96)\end{array}$ & $\begin{array}{l}3.129 * * * \\
(15.64)\end{array}$ & $\begin{array}{l}3.130 * * * \\
(15.74)\end{array}$ \\
\hline Size $_{i t-1}$ & $\begin{array}{l}-0.0615^{* * * *} \\
(-3.42)\end{array}$ & $\begin{array}{l}-0.0630 * * * \\
(-4.01)\end{array}$ & $\begin{array}{l}-0.0379 \\
(-0.79)\end{array}$ & $\begin{array}{l}-0.0340 \\
(-0.88)\end{array}$ & $\begin{array}{l}-0.0677 * * * \\
(-3.39)\end{array}$ & $\begin{array}{l}-0.0673 * * * \\
(-3.84)\end{array}$ \\
\hline $\mathrm{HHI}_{\mathrm{jt}}$ & $\begin{array}{l}-0.673 * * * \\
(-3.96)\end{array}$ & $\begin{array}{l}-0.667 * * * \\
(-5.39)\end{array}$ & $\begin{array}{l}-0.446 * * \\
(-2.43)\end{array}$ & $\begin{array}{l}-0.483 * * * \\
(-3.11)\end{array}$ & $\begin{array}{l}-0.931 * * * \\
(-3.63)\end{array}$ & $\begin{array}{l}-0.936^{* * * *} \\
(-4.68)\end{array}$ \\
\hline $\mathrm{INFL}_{\mathrm{jt}}$ & $\begin{array}{l}0.279 * * * \\
(2.97)\end{array}$ & $\begin{array}{l}0.275^{* * * *} \\
(3.03)\end{array}$ & $\begin{array}{l}0.609 * * * \\
(3.00)\end{array}$ & $\begin{array}{l}0.604 * * * \\
(3.10)\end{array}$ & $\begin{array}{l}0.128 \\
(1.50)\end{array}$ & $\begin{array}{l}0.129 \\
(1.54)\end{array}$ \\
\hline $\mathrm{GGDP}_{\mathrm{jt}}$ & $\begin{array}{l}0.307 * \\
(1.68)\end{array}$ & $\begin{array}{l}0.260 * \\
(1.76)\end{array}$ & $\begin{array}{l}0.661 * \\
(1.79)\end{array}$ & $\begin{array}{l}0.561 * \\
(1.72)\end{array}$ & $\begin{array}{l}0.129 \\
(0.75)\end{array}$ & $\begin{array}{l}0.139 \\
(0.91)\end{array}$ \\
\hline Crisis $_{j t}$ & $\begin{array}{l}0.0543 \\
(1.64) \\
\end{array}$ & $\begin{array}{l}0.0471 \\
(1.59) \\
\end{array}$ & $\begin{array}{l}0.127 \\
(1.51) \\
\end{array}$ & $\begin{array}{l}0.101 \\
(1.27) \\
\end{array}$ & $\begin{array}{l}0.0358 \\
(0.99) \\
\end{array}$ & $\begin{array}{l}0.0369 \\
(1.16) \\
\end{array}$ \\
\hline $\mathrm{N}$ obs. & 3890 & 3890 & 639 & 639 & 3251 & 3251 \\
\hline $\mathrm{N}$ banks & 490 & 490 & 100 & 100 & 390 & 390 \\
\hline R-sq. & 0.336 & & 0.409 & & 0.339 & \\
\hline KP F-Stat. & & $292.6 * * *$ & & $33.87 * * *$ & & $309.8 * * *$ \\
\hline Hansen J-Stat. & & 0.168 & & 0.341 & & 0.241 \\
\hline
\end{tabular}

